\title{
Kajian Independensi Bank Indonesia Dalam Kedudukannya Sebagai Bank Sentral Menurut Tinjauan Hukum Berdasarkan UUBI Nomor 3 Tahun 2004 Tentang Bank Indonesia
}

\author{
Lely Savitri Dewi \\ Institut Manajemen Koperasi Indonesia \\ lelysavitridewi@yahoo.com
}

\begin{abstract}
ABSTRAK
Lembaga negara yang independen, Bank Indonesia adalah badan hukum yang status badan hukumnya diperoleh melalui penetapan Undang Undang (yaitu UU RI Nomor 23 Tahun 1999 jo Undang undang Bank Indonesia Nomor 3 tahun 2004 tentang Bank Indonesia, dimana ditegaskan bahwa Bank Indonesia adalah lembaga negara yang independen baik Pemerintah dan atau pihak lainnya dilarang melakukan campur tangan terhadap pelaksanaan tugas dan wewenang Bank Indonesia (BI). Pelanggaran terhadap larangan campur tangan maupun kewajiban untuk menolak campur tangan, diancam penjara minimal 2 (dua) tahun dan maksimal 5 (lima) tahun serta denda minimal 2 (dua) milyar dan maksimal 5 (lima) milyar. Perlu adanya pemaknaan yang jelas mengenai indepedensi tersebut. Kajian ini bertujuan untuk meninjau kedudukkan hukum Bank Indonesia dari pemegang otoritas moneter berdasarkan Undang Undang Bank/UUBI Nomor 3 Tahun 2004 tentang Bank Indonesia. Metode penelitian melalui deskriptif dengan data sekunder.
\end{abstract}

Kata kunci: independensi bank, bank sentral, Bank Indonesia

\section{ABSTRACT}

An independent state institution, Bank of Indonesia is a legal entity whose legal entity status is obtained through the enactment of Law (ie Law Number 23 of 1999 in conjunction with Bank Indonesia Regulation Number 3 of 2004 concerning Bank of Indonesia, which stipulates that Bank of Indonesia is an independent state institution both the Government and/or other parties are prohibited from interfering in the implementation of duties and authorities of Bank Indonesia (BI) violation of the prohibition of interference or obligation to refuse interference, threatened with imprisonment of at least 2 (two) years and maximum 5 (five) years and fine at least 2 (two) billion and a maximum of 5 (five) billion) The purpose of this study is to review the applicability of Bank of Indonesia law from the holder of monetary authority based on Bank Act/UUBI Number 3 of 2004 concerning Bank of Indonesia. Research method through descriptive with secondary data.

Key words: bank independency, central ank, Bank of Indonesia

\section{PENDAHULUAN}

Kajian ini merangkum dan memahami masalah implementasi dari beberapa aturan perundang undangan yaitu menurut Undang undang Nomor 23 tahun 1999 tentang bank Indonesia, sebagaimana telah diubah dengan “ Undang Undang Nomor 3 Tahun 2004 , terakhir dengan Undang Undang Nomor 6 tahun 2009 tentang Bank Indonesia “ (UUBI). Kedudukan bank Sentral dalam struktur kenegaraan terpatri dalam pasal 23 D UUD 1945 dimana Bank Sentral adalah Bank Indonesia sebagaimana ditentukan dalam pasal 4 ayat (1) UUBI. Berdasarkan hukum Bank Indonesia telah ditentukan sebagai bank Sentral dan kedudukannya diakui oleh konstitusi.

Sebagai Lembaga Negara yang indepedenden, BI adalah badan hukum yang status badan hukumnya diperoleh melalui penetapan Undang-Undang (UU). BI adalah badan hukum publik, dengan kriteria: cara pendiriannya dilakukan penguasa negara berdasarkan UU, pelaksanaan tugasnya berhubungan dengan publik, diberi wewenang membuat peraturan sendiri yang mengikat masyarakat. Saat ini produk peraturan tersebut dituangkan dalam Peraturan Bank Indonesia (PBI).

Adapun wewenang yang diberikan oleh UU kepada BI antara lain wewenang mengelola kekayaan 
sendiri terlepas dari APBN. Independensi BI memberikan kewenangan yang lebih besar kepada BI dengan harapan akan dapat lebih besar meningkatkan efektivitas pelaksanaan Independensi merupakan salah satu isu penting dalam membahas peran Bank Sentral.

Independen berarti bank sentral dapat menggunakan instrumen yang dimilikinya untuk mencapai tujuan yang telah ditetapkan oleh sistem politik tanpa adanya campur tangan dari pihak diluar bank sentral. Ini yang disebut dengan "instrument independence" bukan "goal independence". Konsekwensi independen bagi bank sentral adalah harus lebih akuntabel untuk tindakan yang dilakukan dan kebijakan moneter yang dilakukan secara transparan. Menarik untuk dicermati bahwa meskipun pada awalnya ada keraguan dalam memberikan independensi kepada bank sentral pada akhirnya masyarakat sangat puas terhadap independensi bank sentral

\section{METODE PENELITIAN}

Penelitian ini dilaksanakan dengan menggunakan metode deskriptif yaitu penelitian yang bertujuan untuk menjabarkan suatu kondisi/fenomena yang terjadi saat ini dengan menggunakan prosedur ilmiah untuk menjawab masalah secara aktual. Data yang digunakan merupakan jenis data sekunder yang diperoleh dari laman Bank Indonesia. Obyek tulisan ini tentang permasalahan kedudukan bank Indonesia dari sudut independensi secara kajian hukum menurut Undang Undang Bank Indonesia .

\section{HASIL DAN PEMBAHASAN}

Independesi dan Indikator pencapaiannya Indepedence : " not depending on autority, self governing, not depend on something for validiti or efficiency ... (Riyanto Sastrosdmodjo, 1999) .

Melandaskan kepada makna di atas maka kualifikasi independensi suatu bank Sentral harus memenuhi indikator sebagai berikut :

1) Memiliki kemampuan atau otoritas atau kewenangan judgment dalam kaitannya dengan persoalan kebijakan moneter di negaranya

2) Efekti dan kuat dengan cakupan ekonomi yang luas dalam operasinya

3) Terlepas dari campur tangan partisan serta tekanan partai politik

Bank Indonesia sebagai Institusi negara yang otonom memiliki kewenangan yang jelas berdasarkan Undang undang yang mengaturnya, berikut beberapa telaahan kemandirian $\mathrm{BI}$ menurut UUBI No 3 tahun 2004:

1) Pasal 4 ayat ( 2) UUBI No 3 Tahun 2004

"BI diberi kewenangan menetapkan kebijakan moneter secara independen dan bebas dari campur tangan pemerintah"“

Secara struktural kedudukan BI tidak berada dibawah atau di dalam kabinet Pemerintah, namun mempunyai kedudukan yang sejajar dengan Kabinet Pemerintah

Kemandirian dalam hal penetapan kebijakan moneter merupakan syarat kemandirian instituri, hal ini dipertegas pula dalam pasal 8 huruf a UUBI : BI berwenang utk menetapkan dan melaksanakan kebijakan moneter, mengatur dan menjaga kelancaran sistem pembayaran serta mengatur dan mengawasi perbankan . Kewenangan ini tidak dapat diintervensi Pemerintah ( pasal 9 UUBI Ayat 1.

Dari pembahasan pasal demi pasal di atas maka BI dapat disimpulkan memiliki Kemandirian Institusi.

2) Bank Sentral yang independen harus memiliki kebebasan untuk memutuskan kapan dan dalam hal apa saja fasilitas kredit likuiditas dapat diberikan, hal ini dipertegas pada pasal 10 UUBI: "BI dalam mengendalikan kebijakan moneter berwenang menggunakan instrumen moneter yang telah ditetapkan dalam UU tanpa meminta atau memperoleh persetujuan dari Pemerintah" . Oleh sebab itu jika kemandirian fungsi ini dikaitkan dengan kebijakan Kredit Likuiditas bank Indonesia (KLBI) misalnya, seharusnyalah kebijakan tersebut dialihkan oleh BI kepada pihak lain, karena KLBI dikucurkan terutama untuk membiayai program pemerintah, sehingga bisa mengganggu kemandirian fungsi BI. Oleh sebab itu sangat tepat jika kemudian oleh UUBI di dalam pasal 56 KLBI telah dihapus karena dipandang mengganggu konsep kemandirian .

3) Simpulan dalam pasal 67 jo Pasal 9 UUBI dapat diringkas sebagai berikut : kemandirian Organisasi diperlukan oleh BI karena sangat erta kaitannya dengan komposisi dari organ badan hukum BI dan sistem pengangkatan dan pemberhentian pegawai BI sebagai bank snetral. Puhak lain dilarang melakukan campur tangan terhadap pelaksanaan tugas BI, sebaliknya BI wajib menolak dan atau mengabaikan segala bentuk campur tangan dari pihak luar. Setiap pihak yang melakukan campur tangan dikenakan sanksi yang tegas. Atas dasar penjelasan 
tersebut maka BI harus menegakkan Kemandirian Organisasi dalam pelaksanaan tugasnya sebagai lembaga negara yang independen, diperlukan sikap netral dan tahan terhadap tekanan politik dalam pencapaian kinerjanya .

4) Dalam pasal 60 UUBI No 3 Tahun 2004 Tentang Bank Indonesia ditegaskan bahwa : “ anggaran BI ditetapkan oleh Dewan Gubernur . Tidak perlu aproval DPR , tetapi perlu diinformasikan kepada DPR sebagai bentuk kontrol tidak langsung.

Mengacu pada hal di atas Bank Indonesia memiliki Kemandirian Keuangan secara penuh untuk menjaga peran independensinya secara optimal .

"Beberapa periode lalu independensi dan kemandirian serta kredibilitas BI diuji, karena ditengarai di dalam pelaksanaan BI sebagai Lembaga Negara yang independen, ternyata BI belum mampu menempatkan dirinya sebagaimaan dikehendaki oleh UUBI. Netralitas BI sebagai bank sentral ternyata belum sepenuhnya benar-benar mampu mandiri. Intervensi dan pressure politik masih sering mempengaruhi kinerja dan kebijakan yang dijalankan oleh BI sebagai Lembaga Negara yang independen. Akibatnya begitu BI menjalankan tugas-tugasnya sebagaimana diamanatkan oleh UUBI, banyak pihak kemudian mempermasalahkan landasan hukum kebijakan dalam rangka pelaksanaan tugas BI, status dan kewenangan BI. Tidak mustahil pula kemudian banyak kalangan pemerhati BI yang juga menengarai intervensi dan pressure politik tersebut sebagai upaya lain yang bertujuan merongrong pencapaian kinerja dan pelaksanaan tugas BI" ( Nindyo Pramono, 2010: 10).

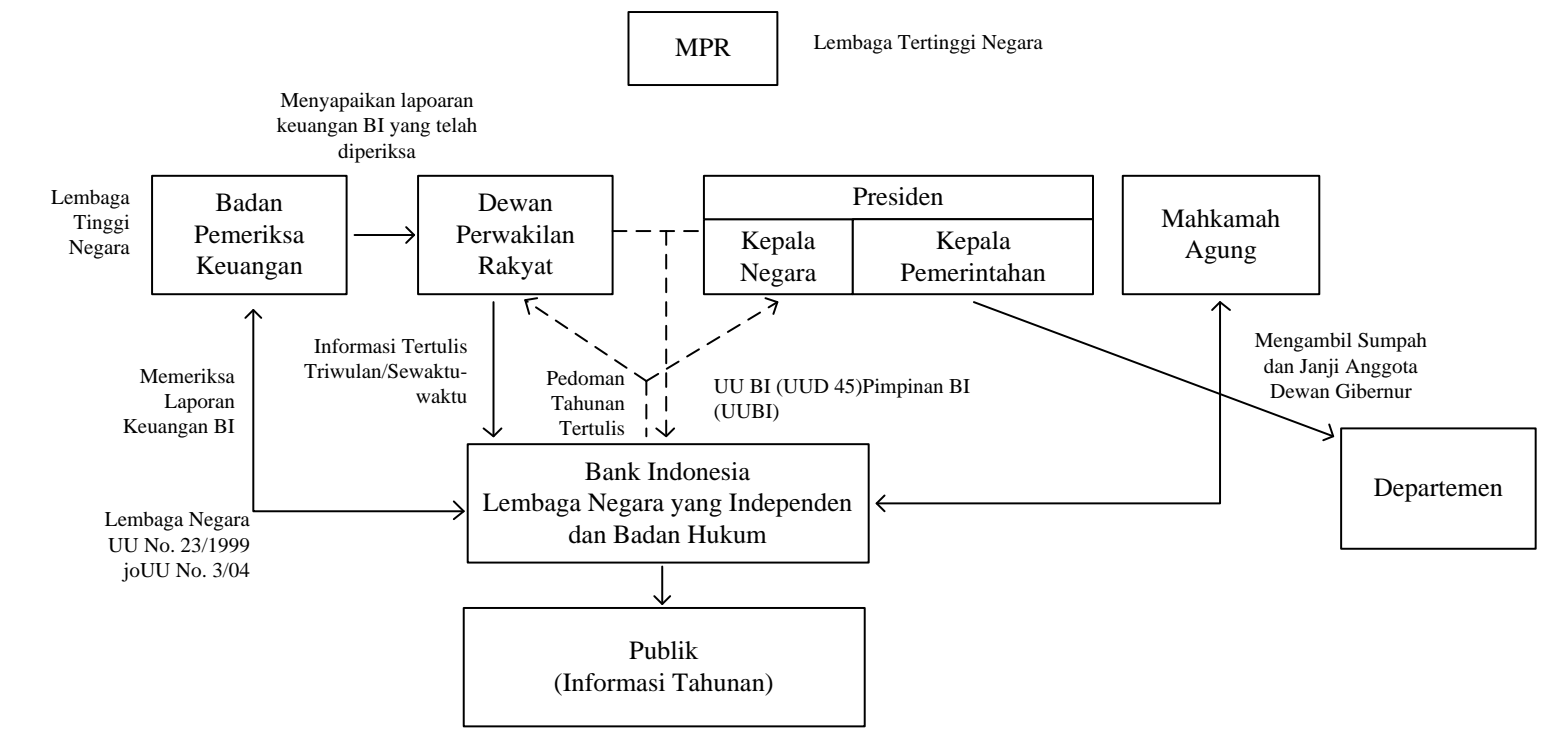

Sumber : Diolah kembali dari BI dan Rahbini, 2000

\section{Gambar 1. Kedudukan Bank Indonesia di dalam Sistem Ketatanegaraan.}

Dari gambar di atas secara legal berdasarkan UUBI dapat dipelajari bahwa kedudukkan BI tidak sejajar dengan lembaga lembaga lainnya, hal ini menunjukkan dengan tegas bahwa BI adalah Lembaga negara bukan lembaga pemerintah (Pasal 4 UUBI No 3/2004 tentang Bank Indonesia). Pemerintah boleh menyusun kabinetnya dan menggantinya setiap saat karena merupakan hak prerogative Presiden, namun untuk posisi BI berdasarkan UU tidak perlu mengikuti arus perubahan kabinet dan atau pemerintahan.

Jadi dalam sistem ketatanegaraan BI adalah lembaga Negara yang independen, tidak berada dalam struktur kabinet dan mandiri. Dalam struktur kenegaraan, hubungan BI dengan lembaga pemerintah digambarkan sebagai berikut :

1) Hubungan dengan Presiden sebagai Kepala Negara, Presiden berwenang:

a) Mengusulkan dan mengangkat Gubernur \& Deputi Senior

b) Mengangkat Deputi Gubernur

c) Mengusulkan calon Gubernur \& Deputi Senior kepada DPR

d) DPR menyampaikan hasil persetujuannya kepada Presiden untuk diangkat 
e) Memberikan persetujuan tertulis jika anggota Dewan Gubernur akan menjalani proses hukum.

2) Hubungan dengan Mahkamah Agung : MA bertugas mengambil sumpah/janji anggota Dewan Gubernur BI

3) Hubungan dengan Badan Pemeriksa Keuangan

a) Menerima dan melakukan pemeriksaan atas laporan keuangan tahunan BI

b) Melakukan pemeriksaan khusus terhadap BI apabila diminta oleh DPR

c) BPK menyampaikan hasil pemeriksaan nya kepada DPR

4) Hubungan Internasional, BI bertugas:

Melakukan kerja sama dengan bank sentral negara lain, organisasi dan lembaga internasional. Apabila keanggotaan suatu lembaga multilateral dipersyaratkan adalah negara, BI dapat berperan sebagai anggota lembaga tersebut untuk dan atas nama Negara

\section{Tujuan Dan Tugas Bank Indonesia}

Menurut Pasal 7 UUBI, BI hanya mempunyai satu tujuan yaitu mencapai dan memelihara kestabilan nilai rupiah. Pencapaian dan pemeliharaan kestabilan nilai Rupiah, tercermin pada:

barang dan jasa $=$ inflasi terhadap mata uang negara lain $=$ kurs

Menurut Pasal 8 UUBI, guna mencapai tujuan kestabilan nilai tukar rupiah, BI memiliki tiga tugas yaitu:

1) Menetapkan dan melaksanakan kebijakan moneter;

2) Mengatur dan menjaga kelancaran sistem pembayaran;

3) Mangatur dan mengawasi bank.

\section{Tugas Penetapan dan Pelaksanaan Kebijakan} Moneter

Dalam rangka melaksanakan tugas menetapkan dan melaksanakan kebijakan moneter, BI menetapkan sasaran inflasi dengan memperhatikan perkembangan dan prospek ekonomi makro, terutama perkembangan harga. Untuk mencapai sasaran laju inflasi, BI menetapkan sasaran besaran moneter atau likuiditas perekonomian.

Pengendalian moneter dilakukan dengan menggunakan berbagai instrumen antara lain Operasi Pasar Terbuka (OPT), penetapan tingkat diskonto, penetapan cadangan wajib minimum, dan pengaturan kredit atau pembiayaan.

Dalam melaksanakan tugas menetapkan dan melaksanakan kebijakan moneter, BI tetap mempunyai fungsi sebagai lender of the last resort yang memungkinkan BI membantu kesulitan pendanaan jangka pendek yang dihadapi bank. Pemberian bantuan dana kepada bank dalam rangka tugas sebagai lender of the last resort tersebut dibatasi jangka waktunya, yaitu paling lama 90 hari; Penggunaannya hanya untuk kepentingan mismatch dan harus dijamin dengan surat berharga yang berkualitas tinggi dan mudah dicairkan. Demikian dapat disimpulkan dari ketentuan Pasal 11 UUBI

\section{Tugas Pengaturan dan Penyelenggaraan Sistem Pembayaran}

Dalam menjalankan tugas pengaturan dan penyelenggaraan sistem pembayaran, menurut Pasal 15 UUBI, BI berwenang:

1) Melaksanakan dan memberikan persetujuan serta izin penyelenggaraan jasa sistem pembayaran

2) Mewajibkan penyelenggara jasa sistem pembayaran untuk menyampaikan laporan kegiatannya

3) Menetapkan penggunaan alat pembayaran

\section{Tugas Pengaturan dan Pengawasan Bank}

Selanjutnya dalam rangka tugas pengaturan dan pengawasan bank, menurut Pasal 24 UUBI, BI berwenang:

1) Menetapkan peraturan di bidang perbankan

2) Memberikan dan mencabut izin atas kelembagaan dan kegiatan tertentu dari bank

3) Melakukan pengawasan bank baik langsung maupun tidak langsung

4) Mengenakan sanksi terhadap bank sesuai dengan ketentuan perundang-undangan

Dari uraian tugas di atas terlihat jelas bahwa sebenarnya posisi BI sebagai bank Sentral sangat terpisah dalam sistem kenegaraan. Dengan demikian BI pemegang kunci sentral dalam melaksanakan tugasnya dalam lingkup:

1) Penetapan dan Pelaksanaan Kebijakan Moneter: BI tetap mempunyai tugas sebagai lender of the last resort yang memungkinkan BI membantu kesulitan pendanaan jangka pendek yang dihadapi perbankan dengan batas waktu paling lama 90 hari dan hanya digunakan bank untuk kepentingan mismatch dan harus dijamin dengan surat berharga yang berkualitas tinggi dan likuid (Pasal 11 UUBI). 
2. Berdasarkan penegasan pasal tersebut sudah seharusnya BI tidak mengani ranah pendanaan Bank yang sedang insolvency karena berisiko tinggi bagi BI jika bank yang dibantu tidak dapat disehatkan kembali. Sebaiknya bantuan pendanan berbentuk modal penyertaan dimana mekanismenya pendanaan akan dicabut kembali (divestasi) kepada investor yang layak dan berminat jika bank yang dibantu sudah dapat dinilai mapan.

2) Pengaturan dan Penyelenggaraan Sistem pembayaran (Pasal 15 UUBI): BI memiki kewenangan penuh dalam hal pemberi persetujuan penyelenggaraan jasa sistem pembayaran, mentapkan penggunaan alat pembayaran dan mewajibkan penyerahan laporan kegiatan bagi jasa penyelenggara pembayaran .

3) Pengaturan dan Pengawasan Bank: BI berwenang dalam hal penetapan aturan Perbankan, Memberikan dan Mencabut izin atas kelembagaan dan keguiatan tertentu bank , mengawasi perbankan secara langsung dan tidak langsung dan mengenakan sanksi terhadap bank sesuai ketentuan UU yang berlaku.

Khusus untuk tugas yang terakhir, kehadiran Otoritas Jasa Keuangan ( OJK ) diharapkan dapat mengawasi dan menyelesaikan Lembaga keuangan Bank maupun Non Bank termasuk pasar modal dan Asuransi dalam masalah kinerja kesehaan usahanya.

\section{KESIMPULAN DAN SARAN}

Berdasarkan pandangan hukum menurut UUBI Nomor 3 tahun 2004 tentang Bank Indonesia sudah cukup jelas bahwa BI memiliki indenpensi dalam ruang lingkup :

a) Kemandirian Institusi ( pasal 4 ayat 2 UUBI )

b) Kemandirian Fungsi (pasal 10 UUBI )

c) Kemandirian Keuangan

d) Kemandirian Organisasi ( pasal 67 jo pasal 9 UUBI Nomor 3 Tahun 2004 tentang Bank

\section{DAFTAR PUSTAKA}

Bank Indonesia. (2002). Mengurai Benang Kusut $B L B I$, Jakarta: Bank Indonesia.

Mintorahardjo, Sukowaluyo. (2001). BLBI Simalakama, Jakarta: Resi.

Nindyo Pramono. (2010) “Implikasi landasan Hukum Independensi dan Posisi Dalm Sistem Ketatanegaraan, Buletin Hukum Perbankan dan Kebanksentralan, ISSN, 1693 - 3205, September 2010
Rahbini, Didik J; Suwidi Tono, 1987, Bank Indonesia Menuju Independensi densi Bank Sentral, Jakarta: PT. Mardi Mulyo.

UUNo. 7 Tahun 1992 jo UU No.10 Tahun 1998 Tentang Perbankan. UU No. 23 Tahun 1999 Tentang Bank Indonesia.

UU NO. 3 Tahun 2004 Tentang Bank Indonesia. 
